\title{
Developmental Brain Asymmetry. The Good and the Bad Sides
}

\author{
Monica Laura Cara ${ }^{1,+}$, Ioana Streata ${ }^{2, \dagger}$, Ana Maria Buga ${ }^{3, *(\mathbb{D})}$ and Dominic Gabriel Iliescu 4 \\ 1 Department of Public Health, University of Medicine and Pharmacy of Craiova, Craiova 200349, Romania; \\ monica.cara@umfcv.ro \\ 2 Human Genomics Laboratory, University of Medicine and Pharmacy of Craiova, Craiova 200349, Romania; \\ ioana.streata@umfcv.ro \\ 3 Department of Biochemistry, University of Medicine and Pharmacy of Craiova, Craiova 200349, Romania \\ 4 Department of Obstetrics and Gynecology, University of Medicine and Pharmacy Craiova, \\ Craiova 200349, Romania; dominic.iliescu@umfcv.ro \\ * Correspondence: ana.buga@umfcr.ro \\ + All these authors contributed equally to this work.
}

Citation: Cara, M.L.; Streata, I.; Buga, A.M.; Iliescu, D.G. Developmental Brain Asymmetry. The Good and the Bad Sides. Symmetry 2022, 14, 128. https://doi.org/10.3390/sym14010128 Academic Editors: David A. Becker and Chiara Spironelli

Received: 7 October 2021 Accepted: 14 December 2021 Published: 11 January 2022

Publisher's Note: MDPI stays neutral with regard to jurisdictional claims in published maps and institutional affiliations.

Copyright: (c) 2022 by the authors. Licensee MDPI, Basel, Switzerland. This article is an open access article distributed under the terms and conditions of the Creative Commons Attribution (CC BY) license (https:/ / creativecommons.org/licenses/by/ $4.0 /)$.

\begin{abstract}
Brain asymmetry is a hallmark of the human brain. Recent studies report a certain degree of abnormal asymmetry of brain lateralization between left and right brain hemispheres can be associated with many neuropsychiatric conditions. In this regard, some questions need answers. First, the accelerated brain asymmetry is programmed during the pre-natal period that can be called "accelerated brain decline clock". Second, can we find the right biomarkers to predict these changes? Moreover, can we establish the dynamics of these changes in order to identify the right time window for proper interventions that can reverse or limit the neurological decline? To find answers to these questions, we performed a systematic online search for the last 10 years in databases using keywords. Conclusion: we need to establish the right in vitro model that meets human conditions as much as possible. New biomarkers are necessary to establish the "good" or the "bad" borders of brain asymmetry at the epigenetic and functional level as early as possible.
\end{abstract}

Keywords: brain; developmental program; asymmetry; gene expression; epigenomics; neurodevelopmental disorders; brain malformations

\section{Introduction}

The mammalian brain is formed by two symmetrical hemispheres that are connected one to each other at both the structural and functional level. This symmetry is only partial in the human brain that displays some degree of asymmetry. Mammalian brain asymmetry was described early in life, starting with the pre-natal period in different areas of the healthy fetus brain [1,2]. This asymmetry becomes more evident later during the post-natal period and it is considered to be a normal process during the developmental period. Brain asymmetry can be related to environmental and development factors that interplay with the brain plasticity process.

Today, brain function lateralization is a well-known process. Each hemisphere collects signals from the opposite part of the body. Recent studies show that a certain degree of abnormal asymmetry of brain lateralization between left-right brain hemispheres can be associated with many neuropsychiatric conditions such as schizophrenia, autism spectrum disorders (AUD), or cerebral palsy [3-6]. The asymmetry of the brain hemispheres is dictated during fetal life through a genetic process [7-9]. However, the molecular signaling pathways linked with brain lateralization patterns during the developmental period are associated with an increased risk of neurological diseases later in life [10].

Later in life, normal and pathological brain aging is associated with different degrees of cortical asymmetry, both at macro and microscopic levels. However, in pathological aging, an accelerated abnormal asymmetry was strongly correlated with neurodegenerative changes in brain structure and alteration of the cognitive function [11,12]. 
In this context, some questions should be solved in order to discover new biomarkers that can predict the neurodevelopmental signature of normal and pathological brain development that can predict CNS (central nervous system) diseases later in life and to establish the early efficient interventions for slowing down the onset of the disease. One important question is if accelerated brain asymmetry is programmed during the prenatal period that can be called "accelerated brain decline clock". If yes, can we find the right biomarkers to predict these changes? Additionally, can we establish the dynamics of these changes in order to identify the right time window for proper interventions that can reverse or limit the neurological decline?

This review focuses on the current findings and future perspectives of brain asymmetry studies as tools of brain remodeling and adaptive changes during the developmental period. These findings are crucial for the management of neuropsychiatric disorders that have a significant socio-economic impact and can significantly improve the quality of life of people at high risk for brain disorders.

\section{Materials and Methods}

We performed a systematic online search in PubMed and Google scholar databases for the last 10 years using the following keywords in different combinations: "brain", "asymmetry", "gene expression", "development", "MRI".

We searched for original articles, meta-analyses, and/or clinical trials published in English. After exclusion of duplicates or articles in languages other than English, we checked for eligibility criteria and we selected only the articles that meet our criteria: original article, clinical studies, clinical trials, randomized clinical controls trial, and/or meta-analysis with relevant content for the purpose of the research. Exclusion criteria were: review articles or case report studies. We included in this study 86 articles focused on the developmental brain, developmental brain lateralization/asymmetry, and neurodevelopmental disorders (Figure 1) [13].
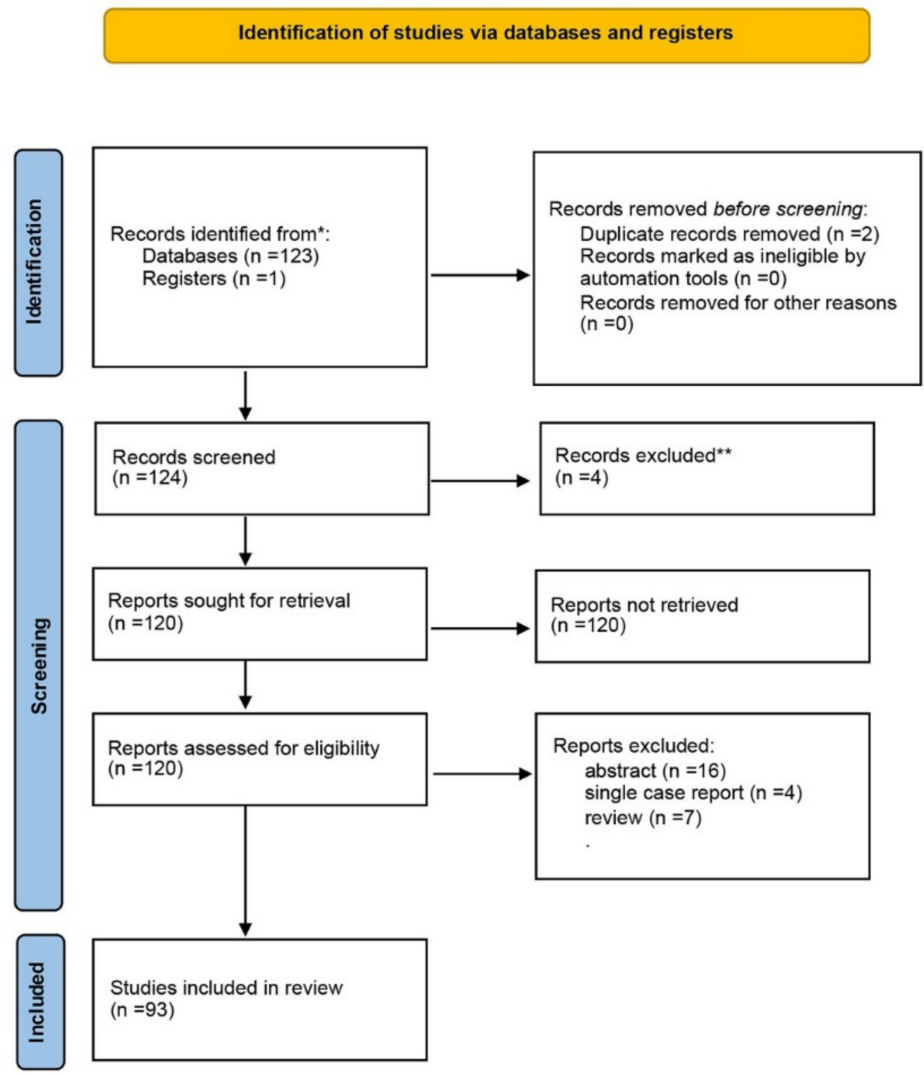

Figure 1. PRISMA diagram for study design. * PubMed Data base. ** Other language than English. 


\section{Results}

\section{1. "Good" Developmental Brain Asymmetry from Gene to Phenotype}

Brain asymmetry is an important feature of the human central nervous system (CNS) organization. Different degrees of asymmetry were described in different brain regions and this asymmetry can be linked with normal brain function and can be called "good brain asymmetry". These degrees of brain asymmetry were described not only at the anatomical level but also at the functional and genetic level and we labeled these genetic events as "genetic clock". The "genetic clock" was studied using animal models, such as primates. However, these findings should be translated for humans. In the first part of our review, we revised the recent findings on normal brain asymmetry ("good brain asymmetry") pattern using a complex view starting with genetic events that drive the normal morphological outcome in a time-dependent manner. In addition, we review here the currently available tools that can be used in order to identify as early as possible the pathological pattern associated with anatomical malformations and/or neuropsychiatric conditions.

\subsubsection{Structural and Functional Asymmetry Lesson learned from In Vivo Studies}

Studies on animal models showed that, during the developmental period, environmental factors can trigger the epigenetic pattern of vulnerable brain tissue and generate fluctuating asymmetry. Fluctuating asymmetry due to environmental exposure was described to be higher in humans compared to monkeys. These findings reflect a stronger influence of different environmental factors that activate brain adaptive mechanisms and can be a key process in human cognitive processes (e.g., neuroplasticity) [14,15].

A comparative study on humans and monkeys showed that the parietal, temporal, and frontal lobes of the human brain display an increased left-oriented asymmetrical connection compared with the brain of primates. This asymmetry pattern has an increased variability between different connectivity of anatomical regions compared to primates [14-16]. This asymmetry can be a hallmark of language and handedness and it was also described in prenatal age [17].

Different degrees of morphological asymmetries in in vivo models in invertebrates, vertebrates, and non-human primates have been described since the 1970s. Nowadays, it is proven that animal models are useful tools to understand the cellular and molecular events that target brain development lateralization $[18,19]$. However, "in mirror", an animal model with human brain asymmetry is difficult to establish since the higher degree of brain asymmetry is a human condition hallmark [16].

In vivo studies on humans are limited to the morphological features of the developmental stages of the brain through the routine use of high-resolution fetal ultrasound and to a lesser extent using the MRI technique (Figure 2). Fetal MRI is recommended only in case of ultrasound abnormality that cannot be clearly described, such as hypoxia ischemia, placenta, or brain abnormalities (e.g., ventriculomegaly or failure to split into the right and left hemisphere) (Figure 3). Additionally, fetal MRI is recommended later in the second or the third trimester of pregnancy (after week 16) when organogenesis is complete and the multilayered structure of the brain is visible [20].

Most CNS anomalies are identified using 2/3D neurosonography performed by an experienced examiner ( $83.7 \%$ of CNS malformations were identified in this way), while fetal MRI is used only in limited cases [21-23]. However, although there are controversial reports on the management of CNS anomalies, some studies show that fetal MRI increases the accuracy of detecting CNS anomalies [24-27]. 


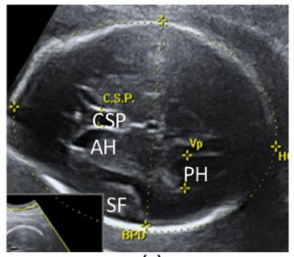

(a)

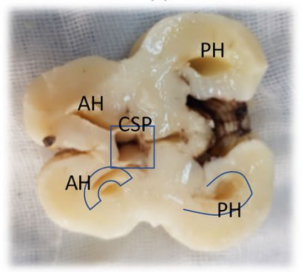

(d)
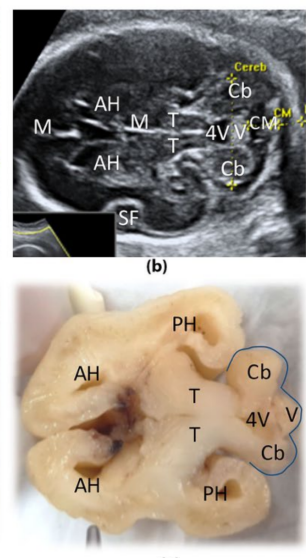

(e)
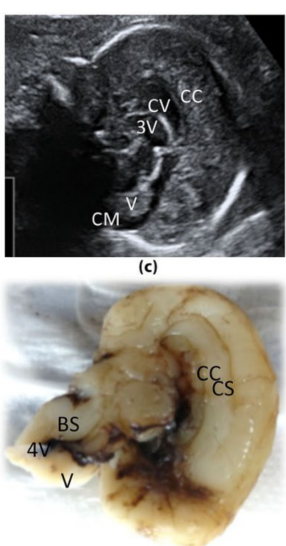

(f)

Figure 2. Ultrasound and pathology correlations in a normal brain. Ultrasound scanning planes and the corresponding planes at fetal brain dissection: (a,d) transventricular; (b,e) transcerebellar; $(\mathbf{c}, \mathbf{f})$ median/midsagittal. The corresponding planes at fetal brain dissection. CSP, cavum septi pellucidi; $\mathrm{AH}$, anterior horns of the lateral ventricles; $\mathrm{PH}$, posterior horns of the lateral ventricles; $\mathrm{SF}$, Sylvian fissure; M, midline/falx cerebri; $\mathrm{T}$, thalamus; $4 \mathrm{~V}$, fourth ventricle; $3 \mathrm{~V}$, third ventricle; $\mathrm{Cb}$, cerebellar hemispheres; V, vermis; CC, corpus callosum; CS, cingulate sulcus; BS, brain stem.
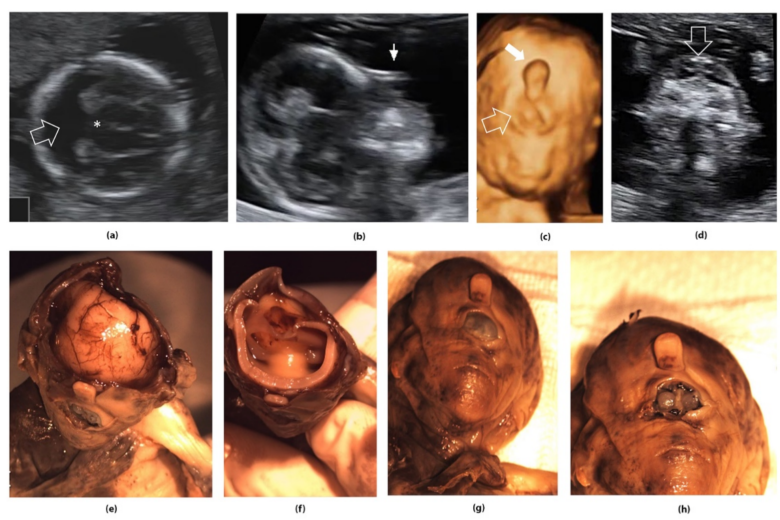

Figure 3. Alobar holoprosencephaly detected in the first trimester of pregnancy (12 weeks of gestation). (a) Absence of the falx cerebri and fusion of the lateral ventricles (arrow) and thalami (star); (b) Proboscis, 2D evaluation; (c) 3D evaluation of the fetal face, showing proboscis (arrow) and cyclopia (open arrow); (d) extreme hypotelorism-synophtalmia (arrow); (e-h) pathology demonstration of the ultrasound findings: complete failure of the brain to divide into right and left hemispheres; (e) with the loss of midline structures of the brain and fusion of the cavities of the brain; (f) proboscis and very closely spaced eyes (synophtalmia/ethmocephaly).

Other previous studies report that both anatomical and functional asymmetry between the left and the right brain hemispheres can be correlated with the dynamics of the transcriptomic process $[1,3,28-30]$. MRI studies of the postnatal period have shown that there is a pattern of interhemispheric asymmetry in newborns and adults as an image of normal brain development [31-33].

Lehtola and colleagues reported an increased volume of the right temporal lobe and the parietal and occipital lobe on the opposite site using MRI [34]. An interesting study using the ex vivo diffusion tractography technique shows a different pattern of asymmetry of the brain region in the prenatal and postnatal periods. It is reported that the anatomical symmetry of the cortical area occurs before the functional asymmetry of the white matter [35].

However, nowadays, technological development has pushed the frontiers of neurodevelopmental research from the morphological aspects of brain development to functional 
assessment. In utero fetal functional MRI (ffMRI) opens new perspectives of functional neural networks. Previous studies showed that the functional connectome started to be mapped by the growth of neuronal cells and the formation of the spine triggering the formation of new neuronal connections according to signals received from different activities [36].

Research studies using ffMRI showed that the functional connectome is formed during the prenatal period (20-40 weeks of gestation) and it seems to be the same as for adults, suggesting that adult motoric and cognitive behavior are established during this period. ffMRI can be a powerful tool for preclinical screening markers that predict neuropsychiatric diseases later in life [37,38]. However, there is a lack of data regarding the left/right symmetry of the functional connectome during the developmental period.

\subsubsection{Genetic Clock in Normal and Pathological Brain Development}

During the developmental period, the human brain is formed due to a very dynamic and complex process. Brain development from neural tube ventrally progresses and the primary part emerges at the end of the sixth week of gestation [39].

This process starts with molecular and cellular interaction (the third week of gestation) until the macroscopic development of the functional brain that continues during the postnatal period [40].

Left and right choroid plexi asymmetry was the first macroscopic interhemispheric asymmetry described since the eleventh week of gestation in the human fetus [39]. The choroid plexus asymmetry can predict other future interhemispheric asymmetries, not only at the structural level but also at the functional level [41].

During this period, genetic and epigenetic changes are key factors that modulate the dynamics of gene expression. Genes that control neuronal pluripotent cells (NPS) are downregulated during the developmental stage. In contrast, genes involved in the differentiation of cells to more specialized types (neurons or glial cells) are upregulated.

\subsubsection{Epigenomic and Transcriptomic Asymmetry as Clue for Normal Brain} Phenotypic Features

Going deeper from the functional connectome to molecular genetics, studies on the level of genes activation in the left and right brain hemisphere in in vivo animal models have shown differential gene expression between the left and right hemispheres. Despite findings from animal models, studies of the human brain report only a discrete asymmetry in the expression of a single gene between the left and the right hemispheres [42]. In this light, we can assume that the asymmetry of human gene expression is not obvious or the asymmetry of the human brain is due to complex phenomena such as: interactions between different gene clusters, epigenetic, and transcriptomic changes.

Recent advances in genomic technologies such as performing whole-genome sequencing (WGS) or whole-exome sequencing (WES) through next-generation sequencing (NGS) methods have made it possible to move genomic analysis from a single gene to the entire human genome. These advances have allowed us to build a complex "story" of functional genomics that underlies the asymmetric pattern of the human brain.

In the last decade, many in vivo studies on animal models have shown differences at the cellular and molecular level between the left and right hemispheres during development. However, research studies so far have focused on establishing a tissue-specific genetic profile and, to a lesser extent, on functional interactions. Recent technological advances are pushing the research area to the next level towards a more complex design. Today, research focuses on the influence of genomic and epigenetic changes on biochemical players (promoter, enhancer, and insulator).

Some databases for mammalians, including humans, are available now (Table 1). 
Table 1. Some human and mice available epigenomic and transcriptomic databases over time.

\begin{tabular}{|c|c|c|c|}
\hline Pipelines & Organism & Registry & Reference \\
\hline FANTOM & RIKE Mice & $\begin{array}{l}\text { cDNA clone functional } \\
\text { annotation }\end{array}$ & $\begin{array}{l}\text { FANTOM3 cDNA Annotation (2 October 2021); } \\
\text { (http:// fantom.gsc.riken.go.jp/db [43] }\end{array}$ \\
\hline CISTROME & $\begin{array}{l}\text { Humans } \\
\text { Mus musculus }\end{array}$ & $\begin{array}{l}\text { Transcription factors } \\
\text { functional annotation or } \\
\text { histone modification }\end{array}$ & $\begin{array}{l}\text { Chromatin Remodeling data (CR Cistrome) (2 October 2021); } \\
\text { (http:/ / cistrome.org) accessed in } 2 \text { october } 2021 \text { [44] }\end{array}$ \\
\hline METHYLOME & $\begin{array}{l}\text { Human } \\
\text { Mouse brain }\end{array}$ & DNA methylation & $\begin{array}{l}\text { MethDB -brain methilation data (4 October 2021) } \\
\text { (http://epigenomics.columbia.edu/methylomedb); [45] }\end{array}$ \\
\hline EPITRANS & Humans & $\begin{array}{l}\text { DNA methylation and histone } \\
\text { modification }\end{array}$ & $\begin{array}{c}\text { Human brain NGS data (4 October 2021) } \\
\text { (http:/ / epitrans.org); [46] }\end{array}$ \\
\hline DEVMOUSE & Mice & Developmental methylome & $\begin{array}{l}\text { Brain methylome (4 October 2021) } \\
\text { (http://www.devmouse.org); [47] }\end{array}$ \\
\hline EpiFactors & Humans & $\begin{array}{l}\text { DNA and histone } \\
\text { modification }\end{array}$ & $\begin{array}{l}\text { Fetal brain expression data (4 October 2021) } \\
\text { (http:// epifactors.autosome.ru); [48] }\end{array}$ \\
\hline miRNA & Mice & $\begin{array}{l}\text { Central nervous system } \\
\text { miRNAs }\end{array}$ & $\begin{array}{c}\text { miRNA } \\
\text { (miRNA.wustl.edu); [49-51] }\end{array}$ \\
\hline SCREEN & $\begin{array}{l}\text { Humans } \\
\text { Mice }\end{array}$ & $\begin{array}{l}\text { cis-regulatory elements } \\
\text { (cCREs) }\end{array}$ & $\begin{array}{l}\text { Registry of cCREs (4 October 2021) } \\
\text { (https://screen.encodeproject.org); [52] }\end{array}$ \\
\hline
\end{tabular}

Many of these databases do not focus on organ-specific genomic and epigenetic changes, and only one of these databases addresses the complex epigenetic mechanisms underlying brain function. In addition, only some of these available tools address the brain developmental period $[47,52]$.

Interestingly, despite the well-known fact that the developmental asymmetry of different brain regions occurs during the prenatal period and may be a key factor for the early onset of brain diseases, none of the available databases provide a complex tool for the left/right asymmetry pattern of cerebral tissue during the lifespan.

A recent study on the genomics of development shows that neurogenesis is one of the main processes that are active from the 10th day of mouse embryonic development until the postnatal period. The active genetic pathways in the early stages of brain development are linked to cell proliferation. Later, during the aging of the brain, this gene expression pattern changes in neuronal cells differentiation, cell migration, and apoptosis [52].

Epigenetic changes in gene expression at the CNS level (neuroepigenetics), without DNA structure alteration, during the developmental period, is an important factor that can change the synthesis of different proteins with impact on brain areas formation (e.g., corticogenesis). Many of these neural epigenetic changes are histone and DNA methylation and/or small non-coding RNAs changes (e.g., miRNA or siRNA), involved in chromatin remodeling, transcriptional regulation, and or/synaptic functioning. These regulatory changes modulate many pathways at the post-transcriptional and post-translational level in response to environmental factors and guide normal or pathological brain development [53].

For the first time, Peng He and colleagues identified a key mechanism that targets new repressors in neuronal gene expression clusters using single-cell RNA-seq and created a more complex database that also includes the biochemical players (promoter, enhancer, and insulator) [52]. However, many research studies are focused on neuroepigenomics and the complex interaction between neural epigenetic and transcriptional factors in relation to environmental factors, both during the in utero and post-natal period.

Transcriptomics is a potential player for brain asymmetry and is directly related to epigenetic changes during the period of brain development. Recent studies have focused on the molecular mechanisms underlying the structural and functional development of the brain, reporting that miRNAs are involved in differential gene expression and functional control between both hemispheres of the human brain [54].

Through microarray analysis, Miao and colleagues identified the interhemispheric asymmetry of miRNAs targeting the main canonical and non-canonical WNT signaling pathways, a key stage involved in brain development [55]. These pathways are related to: 
1. Axons guidance involved in neuronal migration to achieve target and normal neural connections that control healthy brain functions and behavior $[55,56]$;

2. neurotransmitter signaling pathways such as glutamate and $\gamma$-aminobutyric acid (GABA) signaling pathways that regulate the interaction between different areas of the developing brain and are essential for normal brain development. The GABA signaling pathway is also involved in neural plasticity later in adulthood $[55,57,58]$;

3. the dopaminergic pathway is involved in the normal function and behavior of the brain [55]. Here, some major dopaminergic pathways were described: mesocorticolimbic and nigrostriatal pathways that connect the middle brain region with the striatum and prefrontal cortex associated with cognition and motor functions. Dysregulation and disruptions of these pathways are involved in addiction, schizophrenia, ADHD, chorea, and Parkinson's diseases later in life [55,59]. However, if this pattern is asymmetrical, being established during the prenatal period due to complex interaction with genetic or environmental factors, it remains to be elucidated.

Previous studies on animal models and humans showed that the AF (amniotic fluid) can be an important biomarker not only for routine biomarkers. AF composition can be an "in mirror" sample, for both organs development and nervous system diseases, including infectious diseases, brain malformation or for more subtle brain disorders such as autism spectrum disorders [60-62].

An interesting study on the animal model states that the amniotic fluid can be used to assess potential miRNA biomarkers for these functional pathways involved in the normal development of the brain during the prenatal period [63]. miRNAs biomarkers in AF are now well established for Down syndrome

Lehtinen and colleagues showed that the AF composition can be changed in response to environmental factors. These changes release signaling molecules, such as Pals1 and Pten, that can alter the normal neuronal cells proliferation in the cerebral cortex. These cellular and molecular events are associated with anatomical changes, such as cerebral cortex enlargements [61].

An interesting study by Chau and colleagues showed that even after neural tube formation, cells from the neurogenic niche were still under the influence of AF signals that promote identification of the neural cells using BMP, rapamycin (RA), and SHH signaling pathways. This study demonstrates that AF proteomics is altered by environmental and maternal factors too [62]. Another study showed similar findings as the previous one and established that the RA signaling pathway can be a potential tool for predicting fetal malformations and for identifying 20 genes related to CNS that are present in AF [64].

A recent clinical trial performed by Tarca and colleagues established a transcriptomic pattern of AF in normal pregnancy [65]. This clinical trial showed that alternative splicing can be a potential biomarker of brain development during pregnancy [62].

Nowadays, it is well established that miRNA can be detected in AF during pregnancy, and miRNA patterns can be a powerful tool for predicting neurodevelopmental diseases $[63,66]$. Epigenetic studies targeting miRNAs, histone modification, or DNA mutilation signature are novel markers for neurodevelopmental disorders [67]. However, the AF genetic profile is successfully used in other neurodevelopmental diseases such as trisomy 21 and 18 .

Translational studies on AF transcriptome without human amniocytes provide a new future for non-invasive "in mirror" biomarkers not only with normal brain development but also for future brain pathologies [68].

\subsection{Hallmark of "Bad" Developmental Brain Asymmetry}

Presently, there is still a gap of knowledge about how genetic and biological factors, such as age, can influence brain asymmetry. Changes that underlie pathological brain asymmetry were described before to be linked with many neuropsychiatric conditions and can be associated with "bad asymmetry" at anatomical and/or, more subtle, at the molecular level and can be used as pathological signatures. 
Bridge between Neurodevelopmental Brain Signature and Pathological Phenotype

Macroscopic malformations of the CNS are the hallmark of a subtle process, such as genetic and epigenetic processes, that drives CNS formation. However, if the macroscopic features can be identified in utero, the silent or subtle changes are difficult to establish before birth or until later in life.

Dysregulations in gene expression during the developmental period or epigenetic alterations can lead to neurodevelopmental disorders (NDD) such as autism spectrum disorders (ASD) or attention-deficit hyperactivity disorders (ADHD) [69-71].

A GWAS study performed on a large cohort of ADHD people proved that ADHD has a developmental basis linked with neurodevelopmental related genes (NDRG) which are shared with other disorders that appear later in life such as depression or schizophrenia.

Over the last decade, research studies have focused on the highly vulnerable neurodevelopmental period reported that the neuropsychiatric disorders profile is established before birth. Using transcriptomics and epigenomic analysis some studies outlined that the gene expression pattern is established during the prenatal period and remains consistent during the brain development period [72,73].

Using GWAS analysis, a new risk profile is established that overlaps neurodevelopmental genes with genes involved in neurodevelopmental disorders (NDD), ADHD, schizophrenia, and major depressive disorders (MDD) [72]. Li and colleagues reported a time window frame (prenatal weeks 2 and 5) in which these genes displayed a high changes profile [72]. The main protein-coding genes and their transcript functions that are shared between normal developmental CNS period and pathological phenotypes are listed in Table 2.

All these genes and their transcription factors are involved in the major signaling pathway that is active during the developmental period and is critical from normal CNS development, such as: canonical and non-canonical Wnt signaling pathway, FGF signaling pathway, Hedgehog signaling pathway, TGF-beta, or Notch signaling pathways. Some of these signaling pathways act in the early stage of embryogenesis and dictate the first body axis formation which is a crucial step for normal embryonic development future (e.g., Wnt/Hedgehog/Notch pathway). Other pathways act later during the developmental period but are critical for normal cell migration and differentiation. The nuclear hormone receptor signaling pathway contains a high number of different receptors and can trigger at the same time many pathways that are involved in the development and maintenance of different neuronal cells.

Recent advances in molecular techniques proved that this signaling pathway acts asymmetrically between the left and the right part of the brain and has an asymmetric time window.

Alterations in these gene expressions can inhibit or can over-activate, and the signaling pathway can lead to a cellular response that comes too early or too late for normal call communication and that changes the fate of cells during the developmental period. The fate can be of a normal or pathological phenotype that is established early in the developmental period. In addition, these changes can have a significant impact on brain morphology (e.g., malformation) or they can be subtle or silent and can pass without much attention until later in life. Activation or expression of these silent genes can be directly related to environmental factors that can be decisive for diseases onset. 
Table 2. Encoded genes of transcription factors, activators and repressors involved in normal brain development, NDD, and other psychiatric disorders.

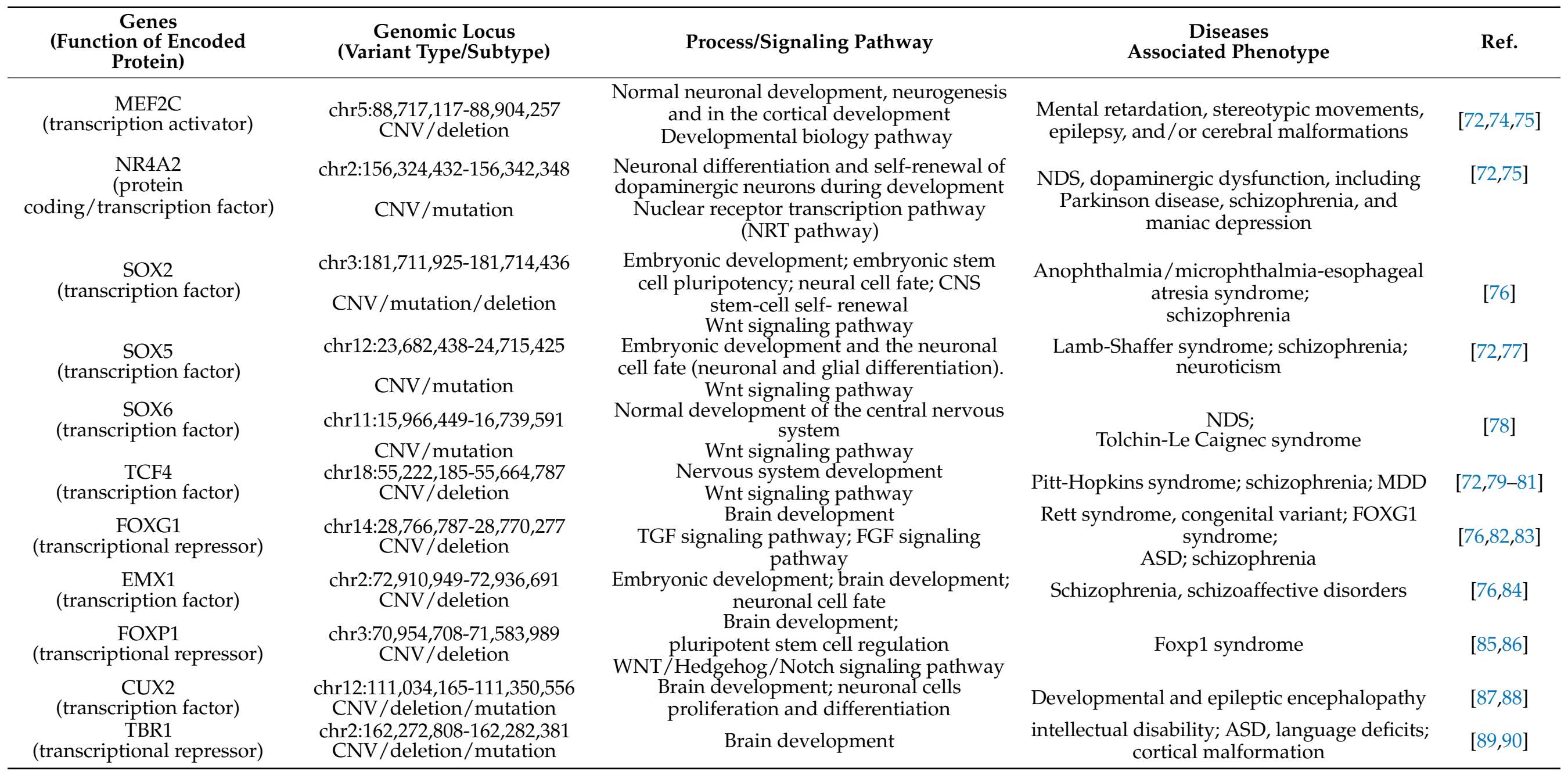


However, at the gene expression level, only a subtle brain asymmetry is described, however, at the transcriptomic level, this asymmetry is more evident and can be explained by the multiregional origin of brain asymmetry [91]. This asymmetric brain pattern is more obvious in relation to brain lateralization/dominance of language or handedness during adult life.

Some studies report an association between psychiatric diseases (e.g., schizophrenia or autism) and brain asymmetry genetic profile and abnormal asymmetry of brain connection [92,93].

There is available evidence proving that upregulation of gene expression is involved in cerebral cortex development, and also collagen-encoded genes are asymmetrically downregulated in the cortex of healthy control and this asymmetry of gene expression is missing in schizophrenia or bipolar disorders [94].

However, it is a complex interaction that cannot be fully replicated in in vitro studies, due to a very sensitive link between environmental factors and cellular signaling pathways during this vulnerable period. Further studies are necessary in order to establish the complex relationship between brain asymmetry genotype/diseases associated phenotype and to set up the right limit between necessary and too much brain asymmetry.

\section{Conclusions}

This paper reviews the currently available evidence related to structural brain asymmetry and molecular and cellular signature of different brain developmental stages. This evidence is a key factor for normal and pathological brain development and there is still a knowledge gap regarding the link between different molecular mechanisms (such as transcriptomics, epigenomics, or cellular reprogramming) and the fate of brain development.

The reviewed article investigates a morphological brain asymmetry in the early developmental period and only a few research articles address the complex process of molecular mechanisms (e.g., gene expression asymmetry, cellular reprogramming, epigenetic changes) and/or environmental interactions during the developmental period. There is a large heterogeneity of study design and techniques that makes it difficult to establish a bridge between morphological and molecular events of brain development at different points in time.

According to the objectives of this review, first, we aimed to bring together available data on molecular mechanisms that can underlie morphological asymmetry in a developmental timeline-dependent manner. Despite normal brain asymmetry and symmetry of gene expression, here, we can identify changes in the transcriptomic profile that can be a bridge between the normal or pathological brain asymmetry during the developmental period and must be further investigated.

Secondly, we aimed to review available data on neurodevelopmental brain signature due to asymmetry of different signaling pathways and dysregulation of gene expression and postnatal brain disorders. This is an important clue in order to find an answer to the question of whether accelerated brain asymmetry is programmed during the pre-natal period.

To date, the fine line between normal and pathological brain asymmetries is not well known. Some future directions have been established using animal models and, in a limited number, on human studies. However, animal models have not been fully replicated "in mirror human" developmental asymmetry conditions. First, a certain degree of structural asymmetry should be clearly established in the mammalian brain, including humans, and is a mandatory form for normal brain functions. We need to establish the right in vitro model that meets human conditions as much as possible.

Second, this structural asymmetry is present early in the developmental period and is not fully replicated by gene expression patterns. This can be explained by reprogramming mechanisms that appear through complex interactions between the neurodevelopmental program and environmental triggers that act to reprogram some neurodevelopmental 
pathways. These environmental factors act more through subtle epigenetic changes at the right time window and can explain the discrepancies between asymmetric brain patterns at the transcriptomic and structural level but are not clearly explained by genetic patterns.

In addition, the main molecular mechanisms that are active during the developmental period underlie the normal or pathological progression of brain development. These molecular mechanisms can promote either a good or a bad asymmetry and can be a potential biomarker (molecular signature) for normal or pathological brain development.

AF contains a large amount of nucleic acids originating from the fetus that make it an "in mirror" tool of gene profile studies for developmental fetal diseases. There is still a knowledge gap regarding the pattern of different epigenetic factors related to the neurodevelopmental period. The limitation in AF studies is related to amniocentesis that is recommended only in pathological pregnancy.

From many previous studies addressing neonatal or adult period, only a few studies have addressed the early gestational stage of brain development (fetal period). The majority of them were designed to study brain asymmetry at the structural level using imaging methods or non-viable fetal brain tissue. The limitation of these studies is that the study findings cannot be correlated with molecular and cellular mechanisms that underlie these structural changes. It is difficult to extrapolate results from independent animal model studies or post-mortem fetal tissue in order to have a complex picture of brain developmental molecular signatures and even more difficult to establish a pathological profile for brain asymmetry at the molecular level. However, there are still contradictory findings regarding the structural brain asymmetry during the prenatal period. Some studies report that the right cortex is developed first compared with the left cortex, but the molecular mechanism that underlies this asymmetry is still unknown. In contrast, studies report a large volume of the left hemisphere compared to the right one. This structural pattern of asymmetry is not described in other brain areas involved in superior functions. There is still a knowledge gap that cannot explain when there is a "good" and "bad" asymmetry and which are the right molecular dynamics of this asymmetry.

Additionally, the majority of brain asymmetry research studies were focused on functional brain asymmetry regarding handedness during the neonatal period. There is still a lack of data regarding brain functional development during the vulnerable prenatal period. These are key future direction points to be addressed that will enable the identification of normal and pathological patterns of brain development as early as possible.

Future studies are needed in order to establish the right biomarkers that target disease programming early in life in order to delay or reverse disease onset. It is necessary to establish the "good" or the "bad" borders of brain asymmetry, not only at the structural level but also at the epigenetic and functional level as early as possible (e.g., in utero). For this, we need to find new novel biomarkers that can better achieve epigenetic changes or different brain area connectomics.

Due to their prevalence and heterogeneity, neurodevelopmental disorders have become an important public health problem. Although researchers have come a long way in understanding neurodevelopmental disorders, further efforts should be made towards a more practical personalized medicine that could help both the patient and healthcare system.

However, this review was limited to molecular mechanisms as a potential bridge between structural pattern dynamics during the developmental period. In order to have a complete scenario of brain development from genotype to morphological and functional phenotype, we must improve this review of currently available data with environmental interactions between brain development. It is well known today that the environment contributes significantly to cellular interactions and reprogramming that can explain pathological future during the brain developmental period. By studying gene expression during brain development and constantly gathering information via WGS and WES, eventually, we will be able to apply epigenetics as a promising therapeutic approach. This will allow us to develop a multimodal approach to prevent or delay neurodevelopmental brain disorders. 
Author Contributions: Conceptualization, A.M.B. and D.G.I.; methodology, A.M.B.; software, M.L.C.; validation, I.S., D.G.I. and M.L.C.; formal analysis, M.L.C.; investigation, M.L.C.; resources, D.G.I.; data curation, A.M.B.; writing-original draft preparation, A.M.B.; writing-review and editing, M.L.C.; visualization, I.S.; supervision, A.M.B. All authors have read and agreed to the published version of the manuscript.

Funding: This research received no external funding.

Institutional Review Board Statement: The study was conducted according to the guidelines of the Declaration of Helsinki, and approved by the Institutional Review Board (or Ethics Committee) of University of Medicine and Pharmacy of Craiova, Romania No. 31/2021.

Informed Consent Statement: Informed consent was obtained from all subjects involved in the study.

Conflicts of Interest: The authors declare no conflict of interest.

\section{References}

1. Kasprian, G.; Langs, G.; Brugger, P.C.; Bittner, M.; Weber, M.; Arantes, M.; Prayer, D. The prenatal origin of hemispheric asymmetry: An in utero neuroimaging study. Cereb. Cortex 2011, 21, 1076-1083. [CrossRef] [PubMed]

2. Andescavage, N.N.; Du Plessis, A.; McCarter, R.; Serag, A.; Evangelou, I.; Vezina, G.; Robertson, R.; Limperopoulos, C. Complex Trajectories of Brain Development in the Healthy Human Fetus. Cereb. Cortex 2017, 27, 5274-5283. [CrossRef] [PubMed]

3. Sha, Z.; Schijven, D.; Francks, C. Patterns of brain asymmetry associated with polygenic risks for autism and schizophrenia implicate language and executive functions but not brain masculinization. Mol. Psychiatry 2021. [CrossRef] [PubMed]

4. Vingerhoets, G. Phenotypes in hemispheric functional segregation? Perspectives and challenges. Phys. Life Rev. 2019, 30, 1-18. [CrossRef]

5. Goel, V. Hemispheric asymmetry in the prefrontal cortex for complex cognition. Handb. Clin. Neurol. 2019, 163, 179-196. [CrossRef] [PubMed]

6. Nelson, K.B.; Blair, E. Prenatal Factors in Singletons with Cerebral Palsy Born at or near Term. N. Engl. J. Med. 2015, 373, 946-953. [CrossRef] [PubMed]

7. Olulade, O.A.; Seydell-Greenwald, A.; Chambers, C.E.; Turkeltaub, P.E.; Dromerick, A.W.; Berl, M.M.; Gaillard, W.D.; Newport, E.L. The neural basis of language development: Changes in lateralization over age. Proc. Natl. Acad. Sci. USA 2020, 117, 23477-23483. [CrossRef] [PubMed]

8. De Kovel, C.G.F.; Lisgo, S.N.; Fisher, S.E.; Francks, C. Subtle left-right asymmetry of gene expression profiles in embryonic and foetal human brains. Sci. Rep. 2018, 8, 12606. [CrossRef] [PubMed]

9. Ocklenburg, S.; Schmitz, J.; Moinfar, Z.; Moser, D.; Klose, R.; Lor, S.; Kunz, G.; Tegenthoff, M.; Faustmann, P.; Francks, C.; et al. Epigenetic regulation of lateralized fetal spinal gene expression underlies hemispheric asymmetries. Elife 2017, 6. [CrossRef] [PubMed]

10. Miller, S.L.; Huppi, P.S.; Mallard, C. The consequences of fetal growth restriction on brain structure and neurodevelopmental outcome. J. Physiol. 2016, 594, 807-823. [CrossRef] [PubMed]

11. Damoiseaux, J.S. Effects of aging on functional and structural brain connectivity. Neuroimage 2017, 160, 32-40. [CrossRef] [PubMed]

12. Roe, J.M.; Vidal-Piñeiro, D.; Sørensen, Ø.; Brandmaier, A.M.; Düzel, S.; Gonzalez, H.A.; Kievit, R.A.; Knights, E.; Kühn, S.; Lindenberger, U.; et al. Asymmetric thinning of the cerebral cortex across the adult lifespan is accelerated in Alzheimer's disease. Nat. Commun. 2021, 12, 721. [CrossRef]

13. Page, M.J.; McKenzie, J.E.; Bossuyt, P.M.; Boutron, I.; Hoffmann, T.C.; Mulrow, C.D.; Shamseer, L.; Tetzlaff, J.M.; Akl, E.A.; Brennan, S.E.; et al. The PRISMA 2020 statement: An updated guideline for reporting systematic reviews. BMJ 2021, 372 , n71. [CrossRef] [PubMed]

14. Gómez-Robles, A.; Hopkins, W.D.; Sherwood, C.C. Increased morphological asymmetry, evolvability and plasticity in human brain evolution. Proc. Biol. Sci. 2013, 280, 20130575. [CrossRef] [PubMed]

15. Gómez-Robles, A.; Hopkins, W.D.; Schapiro, S.J.; Sherwood, C.C. The heritability of chimpanzee and human brain asymmetry. Proc. Biol. Sci. 2016, 283. [CrossRef]

16. Neubauer, S.; Gunz, P.; Scott, N.A.; Hublin, J.J.; Mitteroecker, P. Evolution of brain lateralization: A shared hominid pattern of endocranial asymmetry is much more variable in humans than in great apes. Sci. Adv. 2020, 6, eaax9935. [CrossRef] [PubMed]

17. Cheng, L.; Zhang, Y.; Li, G.; Wang, J.; Sherwood, C.; Gong, G.; Fan, L.; Jiang, T. Connectional asymmetry of the inferior parietal lobule shapes hemispheric specialization in humans, chimpanzees, and rhesus macaques. Elife 2021, 10. [CrossRef] [PubMed]

18. Cochella, L.; Hobert, O. Embryonic priming of a miRNA locus predetermines postmitotic neuronal left/right asymmetry in C. elegans. Cell 2012, 151, 1229-1242. [CrossRef]

19. Chou, M.Y.; Amo, R.; Kinoshita, M.; Cherng, B.W.; Shimazaki, H.; Agetsuma, M.; Shiraki, T.; Aoki, T.; Takahoko, M.; Yamazaki, M.; et al. Social conflict resolution regulated by two dorsal habenular subregions in zebrafish. Science 2016, 352, 87-90. [CrossRef] [PubMed]

20. Rathee, S.; Joshi, P.; Kelkar, A.; Seth, N. Fetal MRI: A pictorial essay. Indian J. Radiol. Imaging 2016, 26, 52-62. [CrossRef] 
21. Paladini, D.; Quarantelli, M.; Sglavo, G.; Pastore, G.; Cavallaro, A.; D’Armiento, M.R.; Salvatore, M.; Nappi, C. Accuracy of neurosonography and MRI in clinical management of fetuses referred with central nervous system abnormalities. Ultrasound Obstet. Gynecol. 2014, 44, 188-196. [CrossRef] [PubMed]

22. Pfeifer, C.M.; Willard, S.D.; Cornejo, P. MRI depiction of fetal brain abnormalities. Acta Radiol. Open 2019, 8, 2058460119894987. [CrossRef]

23. Iliescu, D.; Tudorache, S.; Comanescu, A.; Antsaklis, P.; Cotarcea, S.; Novac, L.; Cernea, N.; Antsaklis, A. Improved detection rate of structural abnormalities in the first trimester using an extended examination protocol. Ultrasound Obstet. Gynecol. 2013, 42, 300-309. [CrossRef] [PubMed]

24. Griffiths, P.D.; Bradburn, M.; Campbell, M.J.; Cooper, C.L.; Embleton, N.; Graham, R.; Hart, A.R.; Jarvis, D.; Kilby, M.D.; Lie, M.; et al. MRI in the diagnosis of fetal developmental brain abnormalities: The MERIDIAN diagnostic accuracy study. Health Technol. Assess 2019, 23, 1-144. [CrossRef] [PubMed]

25. Hart, A.R.; Embleton, N.D.; Bradburn, M.; Connolly, D.J.A.; Mandefield, L.; Mooney, C.; Griffiths, P.D. Accuracy of in-utero MRI to detect fetal brain abnormalities and prognosticate developmental outcome: Postnatal follow-up of the MERIDIAN cohort. Lancet Child Adolesc. Health 2020, 4, 131-140. [CrossRef]

26. Khawam, M.; De Dumast, P.; Deman, P.; Kebiri, H.; Yu, T.; Tourbier, S.; Lajous, H.; Hagmann, P.; Maeder, P.; Thiran, J.P.; et al. Fetal Brain Biometric Measurements on 3D Super-Resolution Reconstructed T2-Weighted MRI: An Intra- and Inter-observer Agreement Study. Front. Pediatr. 2021, 9, 639746. [CrossRef] [PubMed]

27. Schmidbauer, V.U.; Dovjak, G.O.; Yildirim, M.S.; Mayr-Geisl, G.; Weber, M.; Diogo, M.C.; Gruber, G.M.; Prayer, F.; Milos, R.I.; Stuempflen, M.; et al. Mapping Human Fetal Brain Maturation In Vivo Using Quantitative MRI. AJNR Am. J. Neuroradiol. 2021. [CrossRef] [PubMed]

28. Sun, T.; Patoine, C.; Abu-Khalil, A.; Visvader, J.; Sum, E.; Cherry, T.J.; Orkin, S.H.; Geschwind, D.H.; Walsh, C.A. Early asymmetry of gene transcription in embryonic human left and right cerebral cortex. Science 2005, 308, 1794-1798. [CrossRef] [PubMed]

29. Sun, T.; Collura, R.V.; Ruvolo, M.; Walsh, C.A. Genomic and evolutionary analyses of asymmetrically expressed genes in human fetal left and right cerebral cortex. Cereb. Cortex 2006, 16 (Suppl. S1), i18-i25. [CrossRef] [PubMed]

30. Hering-Hanit, R.; Achiron, R.; Lipitz, S.; Achiron, A. Asymmetry of fetal cerebral hemispheres: In utero ultrasound study. Arch Dis. Child Fetal Neonatal. Ed. 2001, 85, F194-F196. [CrossRef] [PubMed]

31. Kong, X.Z.; Mathias, S.R.; Guadalupe, T.; Glahn, D.C.; Franke, B.; Crivello, F.; Tzourio-Mazoyer, N.; Fisher, S.E.; Thompson, P.M.; Francks, C.; et al. Mapping cortical brain asymmetry in 17,141 healthy individuals worldwide via the ENIGMA Consortium. Proc. Natl. Acad. Sci. USA 2018, 115, E5154-E5163. [CrossRef] [PubMed]

32. Kong, X.Z.; Postema, M.; Schijven, D.; Castillo, A.C.; Pepe, A.; Crivello, F.; Joliot, M.; Mazoyer, B.; Fisher, S.E.; Francks, C. Large-Scale Phenomic and Genomic Analysis of Brain Asymmetrical Skew. Cereb. Cortex 2021, 31, 4151-4168. [CrossRef]

33. Habas, P.A.; Scott, J.A.; Roosta, A.; Rajagopalan, V.; Kim, K.; Rousseau, F.; Barkovich, A.J.; Glenn, O.A.; Studholme, C. Early folding patterns and asymmetries of the normal human brain detected from in utero MRI. Cereb. Cortex 2012, 22, 13-25. [CrossRef]

34. Lehtola, S.J.; Tuulari, J.J.; Karlsson, L.; Parkkola, R.; Merisaari, H.; Saunavaara, J.; Lähdesmäki, T.; Scheinin, N.M.; Karlsson, H. Associations of age and sex with brain volumes and asymmetry in 2-5-week-old infants. Brain Struct. Funct. 2019, 224, 501-513. [CrossRef] [PubMed]

35. Song, J.W.; Mitchell, P.D.; Kolasinski, J.; Ellen Grant, P.; Galaburda, A.M.; Takahashi, E. Asymmetry of White Matter Pathways in Developing Human Brains. Cereb. Cortex 2015, 25, 2883-2893. [CrossRef] [PubMed]

36. Thomason, M.E. Structured Spontaneity: Building Circuits in the Human Prenatal Brain. Trends Neurosci. 2018, 41, 1-3. [CrossRef]

37. Turk, E.; Van den Heuvel, M.I.; Benders, M.J.; De Heus, R.; Franx, A.; Manning, J.H.; Hect, J.L.; Hernandez-Andrade, E.; Hassan, S.S.; Romero, R.; et al. Functional Connectome of the Fetal Brain. J. Neurosci. 2019, 39, 9716-9724. [CrossRef] [PubMed]

38. De Asis-Cruz, J.; Barnett, S.D.; Kim, J.H.; Limperopoulos, C. Functional Connectivity-Derived Optimal Gestational-Age Cut Points for Fetal Brain Network Maturity. Brain Sci. 2021, 11, 921. [CrossRef]

39. Abu-Rustum, R.S.; Ziade, M.F.; Abu-Rustum, S.E. Reference values for the right and left fetal choroid plexus at 11 to 13 weeks: An early sign of "developmental" laterality? J. Ultrasound Med. 2013, 32, 1623-1629. [CrossRef] [PubMed]

40. Stiles, J.; Jernigan, T.L. The basics of brain development. Neuropsychol. Rev. 2010, 20, 327-348. [CrossRef]

41. Corballis, M.C. Early signs of brain asymmetry. Trends Cogn. Sci. 2013, 17, 554-555. [CrossRef] [PubMed]

42. Muntané, G.; Santpere, G.; Verendeev, A.; Seeley, W.W.; Jacobs, B.; Hopkins, W.D.; Navarro, A.; Sherwood, C.C. Interhemispheric gene expression differences in the cerebral cortex of humans and macaque monkeys. Brain Struct. Funct. 2017, 222, 3241-3254. [CrossRef]

43. Bono, H.; Kasukawa, T.; Furuno, M.; Hayashizaki, Y.; Okazaki, Y. FANTOM DB: Database of Functional Annotation of RIKEN Mouse cDNA Clones. Nucleic Acids Res. 2002, 30, 116-118. [CrossRef]

44. Liu, T.; Ortiz, J.A.; Taing, L.; Meyer, C.A.; Lee, B.; Zhang, Y.; Shin, H.; Wong, S.S.; Ma, J.; Lei, Y.; et al. Cistrome: An integrative platform for transcriptional regulation studies. Genome Biol. 2011, 12, R83. [CrossRef]

45. Xin, Y.; Chanrion, B.; O’Donnell, A.H.; Milekic, M.; Costa, R.; Ge, Y.; Haghighi, F.G. MethylomeDB: A database of DNA methylation profiles of the brain. Nucleic Acids Res. 2012, 40, D1245-D1249. [CrossRef]

46. Cho, S.Y.; Chai, J.C.; Park, S.J.; Seo, H.; Sohn, C.B.; Lee, Y.S. EPITRANS: A database that integrates epigenome and transcriptome data. Mol. Cells 2013, 36, 472-475. [CrossRef] [PubMed] 
47. Liu, H.; Zhu, R.; Lv, J.; He, H.; Yang, L.; Huang, Z.; Su, J.; Zhang, Y.; Yu, S.; Wu, Q. DevMouse, the mouse developmental methylome database and analysis tools. Database 2014, 2014, bat084. [CrossRef] [PubMed]

48. Medvedeva, Y.A.; Lennartsson, A.; Ehsani, R.; Kulakovskiy, I.V.; Vorontsov, I.E.; Panahandeh, P.; Khimulya, G.; Kasukawa, T.; Drabløs, F.; Consortium, F. EpiFactors: A comprehensive database of human epigenetic factors and complexes. Database 2015, 2015, bav067. [CrossRef] [PubMed]

49. Pomper, N.; Liu, Y.; Hoye, M.L.; Dougherty, J.D.; Miller, T.M. CNS microRNA profiles: A database for cell type enriched microRNA expression across the mouse central nervous system. Sci. Rep. 2020, 10, 4921. [CrossRef]

50. Hoye, M.L.; Koval, E.D.; Wegener, A.J.; Hyman, T.S.; Yang, C.; O’Brien, D.R.; Miller, R.L.; Cole, T.; Schoch, K.M.; Shen, T.; et al. MicroRNA Profiling Reveals Marker of Motor Neuron Disease in ALS Models. J. Neurosci. 2017, 37, 5574-5586. [CrossRef]

51. He, M.; Liu, Y.; Wang, X.; Zhang, M.Q.; Hannon, G.J.; Huang, Z.J. Cell-type-based analysis of microRNA profiles in the mouse brain. Neuron 2012, 73, 35-48. [CrossRef] [PubMed]

52. He, P.; Williams, B.A.; Trout, D.; Marinov, G.K.; Amrhein, H.; Berghella, L.; Goh, S.T.; Plajzer-Frick, I.; Afzal, V.; Pennacchio, L.A.; et al. The changing mouse embryo transcriptome at whole tissue and single-cell resolution. Nature 2020, 583, 760-767. [CrossRef]

53. Bale, T.L. Epigenetic and transgenerational reprogramming of brain development. Nat. Rev. Neurosci. 2015, 16, 332-344. [CrossRef] [PubMed]

54. Kozomara, A.; Birgaoanu, M.; Griffiths-Jones, S. miRBase: From microRNA sequences to function. Nucleic Acids Res. 2019, 47, D155-D162. [CrossRef]

55. Miao, N.; Lai, X.; Zeng, Z.; Cai, W.; Chen, W.; Sun, T. Differential expression of microRNAs in the human fetal left and right cerebral cortex. Mol. Biol. Rep. 2020, 47, 6573-6586. [CrossRef] [PubMed]

56. Kim, S.W.; Kim, K.T. Expression of Genes Involved in Axon Guidance: How Much Have We Learned? Int. J. Mol. Sci. 2020, 21, 3566. [CrossRef] [PubMed]

57. Behuet, S.; Cremer, J.N.; Cremer, M.; Palomero-Gallagher, N.; Zilles, K.; Amunts, K. Developmental Changes of Glutamate and GABA Receptor Densities in Wistar Rats. Front. Neuroanat. 2019, 13, 100. [CrossRef] [PubMed]

58. Luhmann, H.J.; Fukuda, A.; Kilb, W. Control of cortical neuronal migration by glutamate and GABA. Front. Cell Neurosci. 2015, 9, 4. [CrossRef] [PubMed]

59. Yamaguchi, T.; Wang, H.L.; Li, X.; Ng, T.H.; Morales, M. Mesocorticolimbic glutamatergic pathway. J. Neurosci. 2011, 31, 8476-8490. [CrossRef] [PubMed]

60. Petzold, A.; Stiefel, D.; Copp, A.J. Amniotic fluid brain-specific proteins are biomarkers for spinal cord injury in experimental myelomeningocele. J. Neurochem. 2005, 95, 594-598. [CrossRef]

61. Lehtinen, M.K.; Zappaterra, M.W.; Chen, X.; Yang, Y.J.; Hill, A.D.; Lun, M.; Maynard, T.; Gonzalez, D.; Kim, S.; Ye, P.; et al. The cerebrospinal fluid provides a proliferative niche for neural progenitor cells. Neuron 2011, 69, 893-905. [CrossRef] [PubMed]

62. Chau, K.F.; Springel, M.W.; Broadbelt, K.G.; Park, H.Y.; Topal, S.; Lun, M.P.; Mullan, H.; Maynard, T.; Steen, H.; LaMantia, A.S.; et al. Progressive Differentiation and Instructive Capacities of Amniotic Fluid and Cerebrospinal Fluid Proteomes following Neural Tube Closure. Dev. Cell 2015, 35, 789-802. [CrossRef] [PubMed]

63. Sun, T.; Li, W.; Li, T.; Ling, S. microRNA Profiling of Amniotic Fluid: Evidence of Synergy of microRNAs in Fetal Development. PLoS ONE 2016, 11, e0153950. [CrossRef] [PubMed]

64. Hui, L.; Slonim, D.K.; Wick, H.C.; Johnson, K.L.; Bianchi, D.W. The amniotic fluid transcriptome: A source of novel information about human fetal development. Obstet. Gynecol. 2012, 119, 111-118. [CrossRef] [PubMed]

65. Tarca, A.L.; Romero, R.; Pique-Regi, R.; Pacora, P.; Done, B.; Kacerovsky, M.; Bhatti, G.; Jaiman, S.; Hassan, S.S.; Hsu, C.D.; et al. Amniotic fluid cell-free transcriptome: A glimpse into fetal development and placental cellular dynamics during normal pregnancy. BMC Med. Genom. 2020, 13, 25. [CrossRef]

66. Vizitiu, A.C.; Stambouli, D.; Pavel, A.G.; Muresan, M.C.; Anastasiu, D.M.; Bejinar, C.; Alexa, A.; Marian, C.; Sirbu, I.O.; Sima, L. Mature miR-99a Upregulation in the Amniotic Fluid Samples from Female Fetus Down Syndrome Pregnancies: A Pilot Study. Medicina 2019, 55, 728. [CrossRef]

67. Buczyńska, A.; Sidorkiewicz, I.; Trochimiuk, A.; Ławicki, S.; Krętowski, A.J.; Zbucka-Krętowska, M. Novel Approaches to an Integrated Route for Trisomy 21 Evaluation. Biomolecules 2021, 11, 1328. [CrossRef] [PubMed]

68. Kang, J.H.; Park, H.J.; Jung, Y.W.; Shim, S.H.; Sung, S.R.; Park, J.E.; Cha, D.H.; Ahn, E.H. Comparative Transcriptome Analysis of Cell-Free Fetal RNA from Amniotic Fluid and RNA from Amniocytes in Uncomplicated Pregnancies. PLoS ONE 2015, 10, e0132955. [CrossRef] [PubMed]

69. Magnin, E. Neurodevelopmental and Neurodegenerative Similarities and Interactions: A Point of View About Lifelong Neurocognitive Trajectories. J. Alzheimer's Dis. 2021, 79, 1397-1407. [CrossRef] [PubMed]

70. Lewis, E.M.; Kroll, K.L. Development and disease in a dish: The epigenetics of neurodevelopmental disorders. Epigenomics 2018, 10, 219-231. [CrossRef]

71. Loke, Y.J.; Hannan, A.J.; Craig, J.M. The Role of Epigenetic Change in Autism Spectrum Disorders. Front. Neurol. 2015, 6, 107. [CrossRef]

72. Li, M.; Santpere, G.; Imamura Kawasawa, Y.; Evgrafov, O.V.; Gulden, F.O.; Pochareddy, S.; Sunkin, S.M.; Li, Z.; Shin, Y.; Zhu, Y.; et al. Integrative functional genomic analysis of human brain development and neuropsychiatric risks. Science $2018,362$. [CrossRef] [PubMed] 
73. Zhu, Y.; Sousa, A.M.M.; Gao, T.; Skarica, M.; Li, M.; Santpere, G.; Esteller-Cucala, P.; Juan, D.; Ferrández-Peral, L.; Gulden, F.O.; et al. Spatiotemporal transcriptomic divergence across human and macaque brain development. Science 2018, 362. [CrossRef] [PubMed]

74. Posey, J.E.; Rosenfeld, J.A.; James, R.A.; Bainbridge, M.; Niu, Z.; Wang, X.; Dhar, S.; Wiszniewski, W.; Akdemir, Z.H.; Gambin, T.; et al. Molecular diagnostic experience of whole-exome sequencing in adult patients. Genet. Med. 2016, 18, 678-685. [CrossRef] [PubMed]

75. Guo, H.; Duyzend, M.H.; Coe, B.P.; Baker, C.; Hoekzema, K.; Gerdts, J.; Turner, T.N.; Zody, M.C.; Beighley, J.S.; Murali, S.C.; et al. Genome sequencing identifies multiple deleterious variants in autism patients with more severe phenotypes. Genet. Med. 2019, 21, 1611-1620. [CrossRef] [PubMed]

76. Won, H.; De la Torre-Ubieta, L.; Stein, J.L.; Parikshak, N.N.; Huang, J.; Opland, C.K.; Gandal, M.J.; Sutton, G.J.; Hormozdiari, F.; $\mathrm{Lu}, \mathrm{D}$; et al. Chromosome conformation elucidates regulatory relationships in developing human brain. Nature 2016, 538, 523-527. [CrossRef] [PubMed]

77. Lamb, A.N.; Rosenfeld, J.A.; Neill, N.J.; Talkowski, M.E.; Blumenthal, I.; Girirajan, S.; Keelean-Fuller, D.; Fan, Z.; Pouncey, J.; Stevens, C.; et al. Haploinsufficiency of SOX5 at 12p12.1 is associated with developmental delays with prominent language delay, behavior problems, and mild dysmorphic features. Hum. Mutat. 2012, 33, 728-740. [CrossRef] [PubMed]

78. Tolchin, D.; Yeager, J.P.; Prasad, P.; Dorrani, N.; Russi, A.S.; Martinez-Agosto, J.A.; Haseeb, A.; Angelozzi, M.; Santen, G.W.E.; Ruivenkamp, C.; et al. De Novo SOX6 Variants Cause a Neurodevelopmental Syndrome Associated with ADHD, Craniosynostosis, and Osteochondromas. Am. J. Hum. Genet. 2020, 106, 830-845. [CrossRef] [PubMed]

79. Srivastava, S.; Desai, S.; Cohen, J.; Smith-Hicks, C.; Barañano, K.; Fatemi, A.; Naidu, S. Monogenic disorders that mimic the phenotype of Rett syndrome. Neurogenetics 2018, 19, 41-47. [CrossRef] [PubMed]

80. Turro, E.; Astle, W.J.; Megy, K.; Gräf, S.; Greene, D.; Shamardina, O.; Allen, H.L.; Sanchis-Juan, A.; Frontini, M.; Thys, C.; et al. Whole-genome sequencing of patients with rare diseases in a national health system. Nature 2020, 583, 96-102. [CrossRef] [PubMed]

81. Forrest, M.; Chapman, R.M.; Doyle, A.M.; Tinsley, C.L.; Waite, A.; Blake, D.J. Functional analysis of TCF4 missense mutations that cause Pitt-Hopkins syndrome. Hum. Mutat. 2012, 33, 1676-1686. [CrossRef] [PubMed]

82. Seltzer, L.E.; Ma, M.; Ahmed, S.; Bertrand, M.; Dobyns, W.B.; Wheless, J.; Paciorkowski, A.R. Epilepsy and outcome in FOXG1related disorders. Epilepsia 2014, 55, 1292-1300. [CrossRef] [PubMed]

83. Mariani, J.; Coppola, G.; Zhang, P.; Abyzov, A.; Provini, L.; Tomasini, L.; Amenduni, M.; Szekely, A.; Palejev, D.; Wilson, M.; et al. FOXG1-Dependent Dysregulation of GABA/Glutamate Neuron Differentiation in Autism Spectrum Disorders. Cell 2015, 162, 375-390. [CrossRef] [PubMed]

84. Lam, M.; Hill, W.D.; Trampush, J.W.; Yu, J.; Knowles, E.; Davies, G.; Stahl, E.; Huckins, L.; Liewald, D.C.; Djurovic, S.; et al. Pleiotropic Meta-Analysis of Cognition, Education, and Schizophrenia Differentiates Roles of Early Neurodevelopmental and Adult Synaptic Pathways. Am. J. Hum. Genet. 2019, 105, 334-350. [CrossRef] [PubMed]

85. Sollis, E.; Deriziotis, P.; Saitsu, H.; Miyake, N.; Matsumoto, N.; Hoffer, M.J.V.; Ruivenkamp, C.A.L.; Alders, M.; Okamoto, N.; Bijlsma, E.K.; et al. Equivalent missense variant in the FOXP2 and FOXP1 transcription factors causes distinct neurodevelopmental disorders. Hum. Mutat. 2017, 38, 1542-1554. [CrossRef] [PubMed]

86. Trelles, M.P.; Levy, T.; Lerman, B.; Siper, P.; Lozano, R.; Halpern, D.; Walker, H.; Zweifach, J.; Frank, Y.; Foss-Feig, J.; et al. Individuals with FOXP1 syndrome present with a complex neurobehavioral profile with high rates of ADHD, anxiety, repetitive behaviors, and sensory symptoms. Mol. Autism 2021, 12, 61. [CrossRef]

87. Chatron, N.; Møller, R.S.; Champaigne, N.L.; Schneider, A.L.; Kuechler, A.; Labalme, A.; Simonet, T.; Baggett, L.; Bardel, C.; Kamsteeg, E.J.; et al. The epilepsy phenotypic spectrum associated with a recurrent CUX2 variant. Ann. Neurol. 2018, 83, 926-934. [CrossRef] [PubMed]

88. Magno, L.; Asgarian, Z.; Pendolino, V.; Velona, T.; Mackintosh, A.; Lee, F.; Stryjewska, A.; Zimmer, C.; Guillemot, F.; Farrant, M.; et al. Transient developmental imbalance of cortical interneuron subtypes presages long-term changes in behavior. Cell Rep. 2021, 35, 109249. [CrossRef]

89. Bruel, A.L.; Nambot, S.; Quéré, V.; Vitobello, A.; Thevenon, J.; Assoum, M.; Moutton, S.; Houcinat, N.; Lehalle, D.; Jean-Marçais, N.; et al. Increased diagnostic and new genes identification outcome using research reanalysis of singleton exome sequencing. Eur. $J$. Hum. Genet. 2019, 27, 1519-1531. [CrossRef] [PubMed]

90. Den Hoed, J.; Sollis, E.; Venselaar, H.; Estruch, S.B.; Deriziotis, P.; Fisher, S.E. Functional characterization of TBR1 variants in neurodevelopmental disorder. Sci. Rep. 2018, 8, 14279. [CrossRef] [PubMed]

91. De Kovel, C.G.F.; Lisgo, S.N.; Francks, C. Transcriptomic analysis of left-right differences in human embryonic forebrain and midbrain. Sci. Data 2018, 5, 180164. [CrossRef] [PubMed]

92. Ribolsi, M.; Daskalakis, Z.J.; Siracusano, A.; Koch, G. Abnormal asymmetry of brain connectivity in schizophrenia. Front. Hum. Neurosci. 2014, 8, 1010. [CrossRef] 
93. Floris, D.L.; Barber, A.D.; Nebel, M.B.; Martinelli, M.; Lai, M.C.; Crocetti, D.; Baron-Cohen, S.; Suckling, J.; Pekar, J.J.; Mostofsky, S.H. Atypical lateralization of motor circuit functional connectivity in children with autism is associated with motor deficits. Mol. Autism 2016, 7, 35. [CrossRef] [PubMed]

94. Abdolmaleky, H.M.; Gower, A.C.; Wong, C.K.; Cox, J.W.; Zhang, X.; Thiagalingam, A.; Shafa, R.; Sivaraman, V.; Zhou, J.R.; Thiagalingam, S. Aberrant transcriptomes and DNA methylomes define pathways that drive pathogenesis and loss of brain laterality/asymmetry in schizophrenia and bipolar disorder. Am. J. Med. Genet. B Neuropsychiatr. Genet 2019, 180, 138-149. [CrossRef] 